\title{
A Survey on Radio over Fiber (RoF) for Wireless Broadband Access Technologies
}

\author{
R. Karthikeyan \\ Research Scholar, \\ Department of CSA, \\ SCSVMV University, Enathur, \\ Kanchiupram, Tamil Nadu, India.
}

\author{
S. Prakasam, PhD. \\ Asst. Professor, \\ Department of CSA, \\ SCSVMV University, Enathur, \\ Kanchipuram, Tamil Nadu, India.
}

\begin{abstract}
In this paper presents a survey on RoF for Wireless Broadband Access technology like WiMAX (Fixed and Mobile). RoF is considered to achieve an effective delivery of wireless and baseband signal, and it also reduces the power consumption. In the other hand WiMAX (Worldwide Interoperability for Microwave Access) is recent fast growing broadband access technology through wireless. In this paper survey to possible, the RoF implement into wireless broadband access technologies like WiMAX. And also in this combination will be carried out different technical and keying concept from the different methodology.
\end{abstract}

\section{Keywords}

RoF, WiMAX, Wireless Broadband, Fiber Optical, WDM, OFDM.

\section{INTRODUCTION}

Network connectivity can be categorized as a backhaul or an access network. In the access network provide "last mile" connectivity that connects end users to the backhaul network which finally connect to the internet. The copper wires based on DSL, coaxial cable, fixed and mobile wireless etc. The recent generation wireless access network need to increase coverage and high data transmission of voice, video and multimedia services with the fixed and mobile users. For the reason the recent network providers require high transmission bandwidth at the backbone of broadband access technology like WiMAX Base Station (BS). So the Radio-over-Fiber technology uses a key solution for stratifying this requirement. Since the RoF technology had high bandwidth optical system particularly in the backbone wireless and fiber optic technologies. [1]

Radio-over-Fiber (RoF), it refers to a technology light is modulated by the radio signal and it transmitted over an optical fiber link to wireless access like WiMAX BS. In the Radio signal in each signal in each cell are transmitted and received from mobile users by a separate base station via optical fiber. RoF is commonly used for wireless access. In RoF System, wireless signals are transported in optical form between a central station and a set of base stations before using radiated in the air surface. Each base station is adaped to communicate over radio link with at least one user mobile station located in the range of base station. The advantage of this equipment for serving various broadband networks like 3G, 4G, WiMAX and other protocols can be centralized in one place. And the following sections to explain Radio over Fiber and wireless broadband access technology. $[1,2]$

\subsection{Radio-over-Fiber Technology}

Future generation technology, the integration of microwave and optical networks is a solution for increasing capacity and mobility as well as decreasing costs in the access network using RoF architecture. In this architecture can give several advantages such as reduced complexity at the Base Station (BS) antenna side, and radio carriers can be allocated dynamically to the different BS antenna into Sub Stations (SS). If it integrated into broadband technology, this system will need to offer data transmission capacities well standard to the present wireless network. That is Wireless LAN offering up to $54 \mathrm{Mbps}$ and carrier frequencies 2.4 to $5 \mathrm{GHz}, 3 \mathrm{G}$ mobile networks offering up to $2 \mathrm{Mbps}$ in $2 \mathrm{GHz}$, and $4 \mathrm{G}$ offering up to $40 \mathrm{Mbps}$ and 2-8 GHz carrier frequencies. In the recent day main wireless standard such as IEEE 802.16 Mobile and Fixed WiMAX offering 2-66 GHz. It needs to increase capacity frequencies more than $6 \mathrm{GHz}$, which is indoor application the high operating system to access this network. [2, 3, 4]

Radio-over-Fiber technology is use of optical fiber links to distribute RF signals from BS to Remote Antenna Unit (RAU). In the communication system, RF signal processing functions such as frequency up-conversion, carrier modulation, and multiplexing, is performed into the antenna. RoF makes it possible to centralize the RF signal processing function in one headend, then to use optical fiber, which offers low signal loss between $0.3 \mathrm{~dB} / \mathrm{km}$ for $1550 \mathrm{~nm}$ and 0.5 $\mathrm{dB} / \mathrm{km}$ for $1310 \mathrm{~nm}$ wavelength. It distributes the RF signals to the RAUs as shown in the following (see Figure 1).

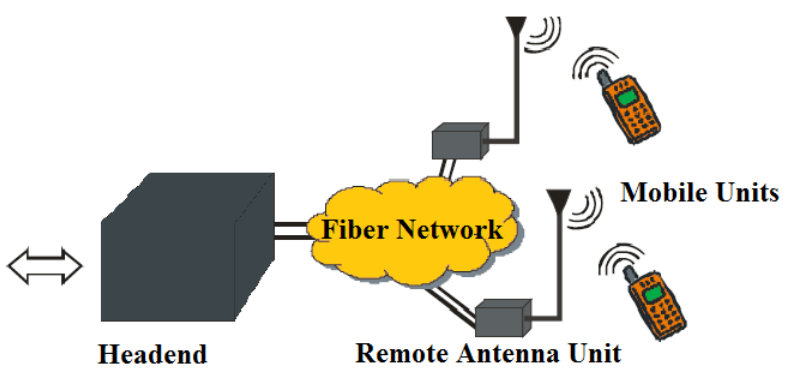

Fig 1: Radio over Fiber System Concept

If the system may be carried GSM and high bandwidth signals, for example RF signal is used to directly modulate the laser and it into sent Central Station. Finally the signal modulated over fiber that is Intensity Modulation with Direct Detection (IM-DD), and it in the RoF link. [5, 6]

\subsubsection{Architecture of RoF}

RoF transmission system are usually classified into two main categories

1. RF-over-Fiber (Radio Frequency over Fiber)

2. IF-over-Fiber (Intermediate Frequency over Fiber) 
In RF-over-Fiber architecture, a data-carrying RF signal with high frequency (greater than $10 \mathrm{GHz}$ ). It is imposed on a light wave signal before transmission over the optical link. Therefore, wireless signals are optically distributed to base stations directly at high frequencies and converted from the optical to electrical domain at the base stations before being amplified and radiated by antenna. As a resultant, no frequency up-down conversion is required at the various base stations.

In IF-over-Fiber architecture, a data-carrying RF signal with lower frequency (less than $10 \mathrm{GHz}$ ). It is used for modulating light before being transported over the optical link. Therefore, before radiation through the air, the signal mush is upconverted to RF at the base station.

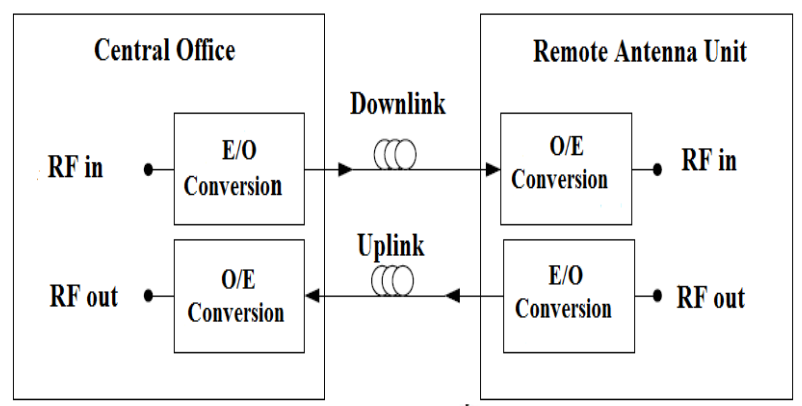

Fig 2: Radio over Fiber System Architecture

A RoF system delivers the RF signal from the CO to the RAU through optical links, an optical link being defined as consisting of all the components required to transfer an electrical signal over an optical carrier as in the figure (see Figure 2). In this diagram explained, the Electrical/Optical conversion can be done by direct modulated laser (or) by an external modulator at the output of RAU. [5, 6].

\subsubsection{Applications of RoF}

There are many applications of RoF technology which consist of satellite communications, mobile radio communications, broadband access, mobile broadband system and wireless LAN. In this section to describe the technical applications of RoF that is Orthogonal Frequency-Division Multiplexing (OFDM), Wavelength Division Multiplexing (WDM), Dense Wavelength Division Multiplexing (DWDM), and Coarse Wavelength Division Multiplexing (CWDMA). Here to explain one of these applications of WDM. [7]

\subsubsection{Wavelength Division Multiplexing (WDM) in RoF System.}

WDM are combining light with different wavelength, coming from different fiber, on to a single fiber. They consist of DWDM, device that use optical (analog) multiplexing techniques to increase the carrying capacity of fiber networks that can be use through Time Division Multiplexing (TDM). The use of WDM for distribution of RoF signal in the following figure (see Figure 3).

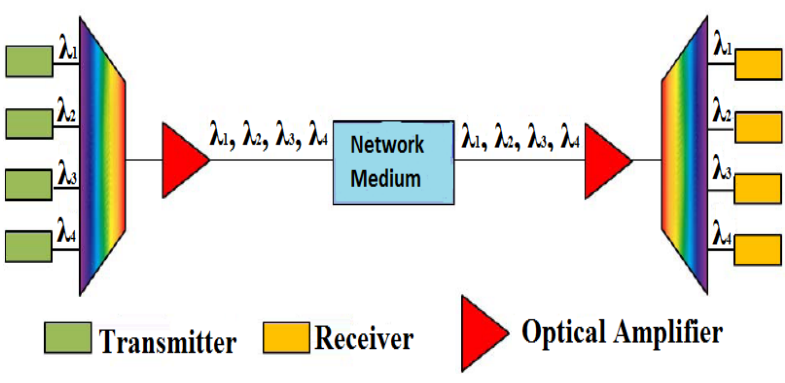

Fig 3: WDM transmission

It enables the effective output of the fiber network bandwidth. This system can achieve capacities over 1 Tbps over single fiber. At the same time bit rate on a signal channel have rice $10 \mathrm{Gbps}$ to $40 \mathrm{Gbps}$ for channel rates. The channel spacing in WDM can be decreased to $50 \mathrm{GHz}$ or $25 \mathrm{GHz}$, in this time possible to transmit 100 of channels. However, transmission of RoF signal is seen as inefficient in terms of spectrum utilization, and since the modulation bandwidth is always a small fraction of carrier frequency signal. RoF on WDM system have been modulated with using Optical Add-Drop Multiplexer (OADM). [7]

\subsubsection{Benefits of RoF technology}

Some benefits of the RoF technology as given below.

- Low Attenuation Loss

- $\quad$ Large Bandwidth

- $\quad$ Reduced Power Consumption

- Dynamic Resource Allocation

\subsubsection{Limitations of RoF technology}

Recent RoF technology involve analogue modulation, and detection of light, it is fundamentally and analogue transmission system. Therefore, signal impairments such as noise and distortion are important to analog communication system and RoF technology as well. These impairments is limit the Noise Figure (NF) and Dynamic Range (DR) of the RoF links. The DR is also important of mobile communication systems for signal received at the BS from the MUs. That is the RF power received from a MU is close to BS and also much higher than RF power received from MU in which several kilometers away. But it within the same cell.

In Single Mode Fiber (SMF) based RoF systems may limit the fiber link length and my also lead to increasing RF carrier phase noise. In Multi Mode Fiber (MMF) based RoF system, model several limits that is available link and bandwidth and distance. If it may be digital using multi signal modulation formats such as Orthogonal Frequency Division Multiplexing (OFDM) then it being distributed to any other transmission systems. [7]

\subsection{Wireless Broadband}

The wireless broadband or wireless access technology that are classified WiFi, WiMAX, mobile broadband, wireless network and satellite based technologies. The recent wireless broadband technology is for fixed and mobile that is WiMAX (The Worldwide Interoperability for Microwave Access). The standard of IEEE 802.16d for fixed WiMAX and IEEE 802.16e for Mobile WiMAX. And the frequencies for broadband wireless communication system in the following table 1 . 
Table 1: Frequencies for Wireless Broadband [5, 6]

\begin{tabular}{|c|l|}
\hline Frequency & \multicolumn{1}{|c|}{ Wireless System } \\
\hline $2 \mathrm{GHz}$ & UMTS/ 3G Systems \\
\hline $2.4 \mathrm{GHz}$ & IEEE 802.11 b/g WLAN \\
\hline $5 \mathrm{GHz}$ & IEEE 802.11 a WLAN \\
\hline $2-11 \mathrm{GHz}$ & IEEE 802.16 WiMAX \\
\hline $17 / 19$ & Indoor Wireless (Radio) LANs \\
\hline $28 \mathrm{GHz}$ & $\begin{array}{l}\text { Fixed Wireless access - Local point to } \\
\text { Multipoint (LMDS) }\end{array}$ \\
\hline $38 \mathrm{GHz}$ & Fixed Wireless access \\
\hline $58 \mathrm{GHz}$ & Indoor Wireless LANs \\
\hline $57-64 \mathrm{GHz}$ & IEEE 802.16 WPAN \\
\hline $10-66 \mathrm{GHz}$ & IEEE 802.16 WiMAX \\
\hline
\end{tabular}

From table, WiMAX system to offer need high capacity and it appears to increase the carrier frequencies and to reduce cell sizes. The IEEE $802.16 \mathrm{WiMAX}$ range $2-11 \mathrm{GHz}$ for mobility support. And the IEEE 802.16 WiMAX range 10-66 GHz it's for fixed wireless broadband.

\subsubsection{Architecture of WiMAX}

WiMAX deals with both point-to-point (P-P) and point-tomultipoint (P-MP) networks. PP networks can easily deploy and it can provide high speed data with minimum interference. It can provide last mile solution. This P-P network usually takes less operating and maintenance cost and can provide direct services to the end users. On the other hand P-MP network can provide services to hundreds of subscribers within a single radio environment. Here by using multiplexing and queuing method, many subscribers uses the single radio channel for its communication.

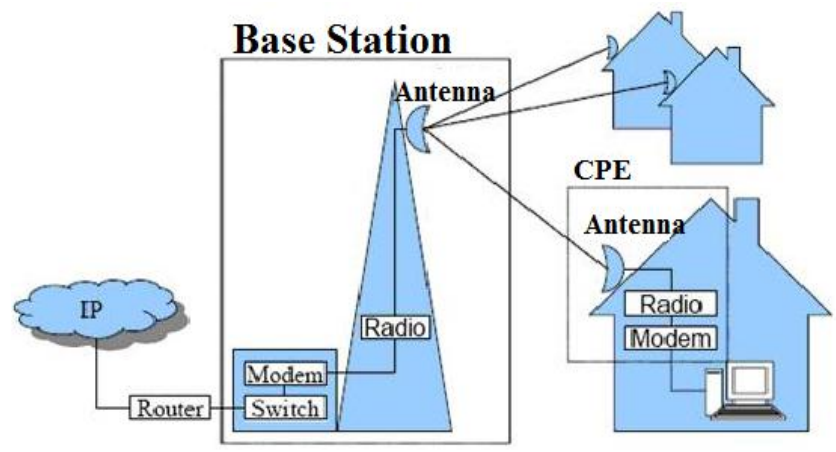

Fig 4: WiMAX Network Architecture

Figure (see Figure 4) shows the network topology of WiMAX where two WiMAX base stations are connected with point-topoint microwave link. Base station is usually connected with the core network by fiber optic cable. WiMAX subscriber station could be mounted on the rooftop of the customer premises equipment which can establish high speed line of sight connection with the base station or the base station could provide point to multipoint link which is cost effective and work even in obstructed environment. [8].

\subsubsection{Applications of WiMAX}

The technical applications of WiMAX, it supports several multiplexing concept. Particularly for Broadband access network through the wireless support OFDM for fixed and
OFDMA for mobile. OFDM is a digital modulation scheme especially for broadcasting. It can handle multipath propagation and delays between received signals. The OFDM is sensitive to frequency changes at the mobile stations when it moving. At a same way OFDMA is a version of OFDM and for several user mobile communication environments. It is solution considered to be the modulation scheme in most advantages for wireless communication technologies. It possible access for Mobile WiMAX, it they presenting number of subscribers in $3 \mathrm{G}$ and $4 \mathrm{G}$ also. [1,9]

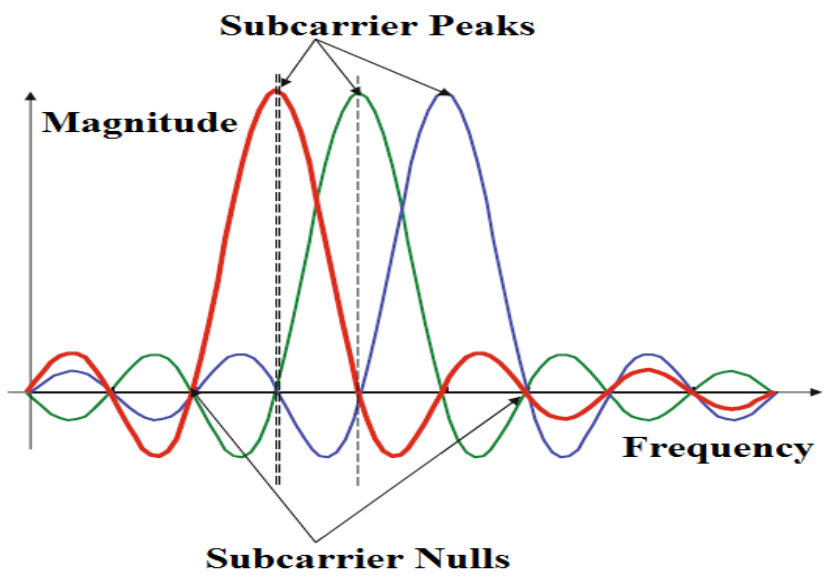

Fig 5: OFDM Multicarrier System

From the figure (see figure 5), Orthogonal is a property that allows the signals to be perfectly transmitted over a common channel and detected without interference. For OFDM signal, the peak of one sub carrier coincides with the null of the other sub carriers. Thus no interference from other sub carriers at the peak of spectrums overlaps. [1,14]

\subsubsection{Advantages of OFDM Systems}

- OFDM sub carriers do not interfere with each other. OFDM can be used for high-speed multimedia applications with lower service cost.

- OFDM can support dynamic packet access. In the smart antenna can be integrated with OFDM. And MIMO system can be obtained easily with OFDM.

- It is more flexible for single frequency network, especially for broadcast applications.

- $\quad$ As OFDM transmitter simplifies the channel estimator for different modulator scheme.

- It is equalization is very simple compared with to Single-Carrier systems.

- OFDM, it able to protect energy loss at frequency domain.

\section{LITERATURE SURVEY}

The following table 2 shows, the methodology starts with literature study and review on overall RoF system. These papers had different kinds of methods. And but following section to discussion about this literature table. 
Table 2. Comparison of various RoF.

\begin{tabular}{|c|c|c|}
\hline $\begin{array}{c}\text { Method \& } \\
\text { Author Name }\end{array}$ & Objectives & Result \\
\hline $\begin{array}{l}\text { To proposed digitized RF over Fiber link } \\
\text { MATLAB Simulation tool. - Beena R Ballel } \\
\text { and Dr. Shikha Nema } \\
\text { May } 2012[10,18]\end{array}$ & $\begin{array}{l}\text { Here using ditial RoF not ARoF. RoF } \\
\text { Access point only for Digital }\end{array}$ & $\begin{array}{l}\text { Method using MATLAB simulation } \\
\text { tools prove about only DRoF not } \\
\text { ARoF. }\end{array}$ \\
\hline $\begin{array}{l}\text { Using Amplifier and equipments. } \\
-\quad \text { Haruka Mikamori, Koyu Chinen } 2011 \\
\text { [11] }\end{array}$ & $\begin{array}{l}\text { Design E/O and O/E for access point of } \\
\text { WiMAX-RoF. Uplink design. Receiving } \\
\text { signal from mobile terminal is very low. } \\
\text { Use SMF }\end{array}$ & $\begin{array}{l}\text { Method are using only amplifier, not } \\
\text { using any tools. }\end{array}$ \\
\hline $\begin{array}{l}\text { Three method implemented into RoF. i.e. } \\
\text { SCM, WDM, and OFDM. And compare with } \\
\text { following parameter: Attenuation, Scattering, } \\
\text { Dispersion, BER, and CNR. By } \\
\text { - Ajay Kumar Vyas and Dr. Navneet } \\
\text { Agarwal } 2012 \text { [19] }\end{array}$ & $\begin{array}{l}\text { RoF integration microwave and optical } \\
\text { communication are access to broadband } \\
\text { wireless communications. }\end{array}$ & $\begin{array}{l}\text { RoF techniques are smoothly merged } \\
\text { with broadband access optical network } \\
\text { like WDM, SCM \& OFDM. So Future } \\
\text { Challenged RoF deploy into mobile, } \\
\text { 3G,Wi-Fi, WiMAX and Wireless } \\
\text { access over fiber technology. }\end{array}$ \\
\hline $\begin{array}{l}\text { Up conversion technique using } \\
\text { SPICE-BJT model } \\
\text { (Simulation program with Integrated Circuit } \\
\text { Emphasis 9.2). } \\
\text { This is model carried out up-conversion } \\
\text { Frequency and Time domains. - N.Mohmad, } \\
\text { S.M. Idrus, A.B. Mohammad, H. Harun, R. } \\
\text { Mohamad and S. Yaakob 2012 [8] }\end{array}$ & $\begin{array}{l}\text { Involve IF signal over fiber present in up } \\
\text { conversion (BS -> CO). } \\
\text { The system implemented to detect a } 0.4 \\
\mathrm{GHz} \text { of IF carriers signal and up-converted } \\
\text { to } 3.4 \mathrm{GHz} \text { of RF signal. This paper } \\
\text { present on frequency conversion } \\
\text { technique. }\end{array}$ & $\begin{array}{l}\text { IF optical conversion input power used } \\
\text { and front-end receiver has achieved a } \\
\text { good conversion at different } \\
\text { frequencies. }\end{array}$ \\
\hline $\begin{array}{l}\text { Transmission of OFDM signals over RoOW } \\
\text { using mathematical modeling method. } \\
\text { Analyzing SNR and channel Allocation. } \\
\text { BER calculated for OFDM signal at different } \\
\text { wave environment. - Jiang Liu, Wasinee } \\
\text { Noonpakdee, Shigeru Shimamoto. } 2011 \text { [12] }\end{array}$ & $\begin{array}{l}\text { OFDM based RoF i.e. (RoOW) Radio over } \\
\text { Optical Wireless. } \\
\text { Here using the system of (IM/DD) } \\
\text { Intensity-Modulated/Direct-Detection to } \\
\text { RF subcarrier modulation considered } \\
\text { (OFDM-RF) signal. }\end{array}$ & $\begin{array}{l}\text { Resultant when optical power is larger } \\
\text { then }-20 \mathrm{dBm} \text { then value of BER } \\
\text { almost independent of optical power } \\
\text { emit ion. }\end{array}$ \\
\hline $\begin{array}{l}\text { Implementing R\&F into three levels PON, } \\
\text { AON, and Wireless Architectures. } \\
-\quad \text { T. Tsagklas and F.N. Pavlidou. } \\
2011 \text { [13] }\end{array}$ & $\begin{array}{l}\text { Goal of FiWi is coverage various optical } \\
\text { wireless technologies under single } \\
\text { infrastructure. } \\
\text { It's both fixed and mobile. } \\
\text { R\&F - its support different protocol }\end{array}$ & $\begin{array}{l}\text { FiWi networks comprise a new } \\
\text { emerging technology combines both } \\
\text { optical and wireless networks. And } \\
\text { also it support QoS, routing } \\
\text { algorithms, optical gateway for traffic } \\
\text { control, handover schemes. }\end{array}$ \\
\hline $\begin{array}{l}\text { This operation arise from Mach Zehnder } \\
\text { Modulator (MZM) } \\
\text { - } \quad \text { Mazin Al-Noor Jonathan Loo, Richard } \\
\text { Comley. } 2011[1,14]\end{array}$ & $\begin{array}{l}\text { Main implementation of this paper is long } \\
\text { distance signal transmission through RoF. } \\
\text { Decreasing power consumption and } \\
\text { increasing data bit rate in RoF. Implement } \\
\text { three type of fibers i.e. SMF, DCF and } \\
\text { CFBG. } \\
\text { CFBG is used transmit } 120 \text { mbps in } \\
\text { mobile WiMAX (SOFDM) at } 3.5 \mathrm{GHz} \\
\text { carrier frequency } 20 \mathrm{MHz} \text { in RoF. }\end{array}$ & $\begin{array}{l}\text { RF over RoF using WiMAX signal } \\
\text { able to carry S-OFDMA. } \\
\text { From the result WiMAX downlink } \\
\text { signal iproved compare to energy } \\
\text { consumptions BS antenna ( } 167.57 \mathrm{~dB} \\
\text { for } 5 \mathrm{~km} \text { at data bit rate } 120 \mathrm{mbps}) \text {. } \\
\text { Future work: } \\
\text { Possible to increasing signal } \\
\text { transmission for various mobile and } \\
\text { fixed broadband systems such as } \\
\text { WiMAX and UWB. }\end{array}$ \\
\hline $\begin{array}{l}\text { Here using the method based Chromatic } \\
\text { dispersion and non-linearity scattering } \\
\text { implement two power level minimum } \\
\text { (Brillouin power) and maximum (Raman } \\
\text { power) } \\
\text { - Jalal J. Hamad Ameen, Widad Ismail } \\
\text { and Sevia M. Edrus 2011 [15] }\end{array}$ & $\begin{array}{l}\text { Proposed Radio over Fiber and power } \\
\text { management technique is introduced. } \\
\text { It proposed better power level for } 4 \mathrm{G} \\
\text { mobile base stations with expected } \\
\text { coverage area, and power control and } \\
\text { signal improvement for the system. }\end{array}$ & $\begin{array}{l}\text { RoF link optimizes minimum and } \\
\text { maximum power launched into the } \\
\text { fiber is better than base station in the } \\
\text { network. } \\
\text { For long distances result SMF is } \\
\text { advantages of MMF. } \\
\text { For small distances is better MMF. } \\
\text { Resultant } 4 \mathrm{G} \text { base station covers about } \\
2-3 \mathrm{~km} \text { radius the SMF is preferred. }\end{array}$ \\
\hline
\end{tabular}




\section{DISCUSSION}

- RoF is a flexible and cost effective technique and that enable multiple functionality. And in this technique is reducing the attenuation, dispersion, scattering.

- It can be improving bandwidth. Here frequency multiplexing (OFM), into OFDM then we get a better solution for future for mobile broadband network. $[10,18]$

- DRoF and ARoF in these two methods very used full to the data transmission over RF. Because ARoF through RF for voice conversion and DRoF through the data conversion technique. [1].

- In this statement clear to say at the WiMAX RoF transmission less then $40 \mathrm{Km}$ and it satisfy lower cost of power consumption less than $-30 \mathrm{~dB}$. But it will increase the down link transmission of power consumption is in the optical to electrical conversion (O-E) in the access points. [3]

- In uplink transmission need to used low noise for the receiver.[3]

- Relay system received optical power is larger than $-20 \mathrm{dBm}$, it is practical power level. In this value implement upto $30 \mathrm{~dB}$ that means the system as long as to access inaccessible areas. [5]

- The up conversion technique is used, that is (BS to $\mathrm{CO}$ ). Here only using IF (Intermediate frequency) signal over fiber present in the front end, and receiver using transistor.

- If the system implements to detect $0.4 \mathrm{GHz}$ signal only to carrying up conversion in the RF signal.

- Time and frequency domain with OFDM conversion technique is easily maintained. Because the up conversion signal is less then $10 \mathrm{GHz}$. So the data are reduced when it send.

- In future it will implement in millimeter wave with RoF it to clarify both up and down conversion easily. [4]

- RoF and WiMAX, the both common method is WDM and OFDM. These two methods are implemented easily into future broadband access technologies.

- Uplink and downlink transmission in RoF are presented not together. But in WiMAX both are presented together.

- Possible to increasing signal transmission for various mobile and fixed broadband systems such as WiMAX and UWB.[14]

- $\quad$ RoF link optimizes minimum and maximum power launched into the fiber is better than base station in the network. For long distances result SMF is advantages of MMF. For small distances is better MMF. Resultant 4G base station covers about 2-3 $\mathrm{km}$ radius the SMF is preferred. [15]

\subsection{Comparison of Broadband Access Technology with RoF (WiMAX -RoF)}

Table 3. WiMAX with RoF

\begin{tabular}{|c|c|c|c|}
\hline Parameter & $3 G$ & $4 G$ & $\begin{array}{c}\text { WiMAX with } \\
\text { RoF }\end{array}$ \\
\hline $\begin{array}{l}\text { Data } \\
\text { throughput }\end{array}$ & $\begin{array}{l}\text { Up to } 3.1 \\
\text { Mbps }\end{array}$ & $40 \mathrm{Mbps}$ & $75 \mathrm{Mbps}$ \\
\hline $\begin{array}{l}\text { Services and } \\
\text { Applications }\end{array}$ & CDMA & $\begin{array}{l}\text { WiMAX2, } \\
\text { LTE }\end{array}$ & $\begin{array}{l}\text { Optical fiber } \\
\text { into WiMAX }\end{array}$ \\
\hline $\begin{array}{l}\text { Frequency } \\
\text { Band }\end{array}$ & $\begin{array}{l}1.8-2.5 \\
\mathrm{GHz}\end{array}$ & $2-8 \mathrm{GHz}$ & $10-66 \mathrm{GHz}$ \\
\hline $\begin{array}{l}\text { Network } \\
\text { Architecture }\end{array}$ & $\begin{array}{l}\text { Wide area } \\
\text { cell based }\end{array}$ & $\begin{array}{l}\text { Integration } \\
\text { of wireless } \\
\text { LAN and } \\
\text { Wide are }\end{array}$ & $\begin{array}{l}\text { Integration of } \\
\text { fiber optical } \\
\text { into WiMAX }\end{array}$ \\
\hline $\begin{array}{l}\text { Switching } \\
\text { technique }\end{array}$ & $\begin{array}{l}\text { Packet } \\
\text { switching }\end{array}$ & $\begin{array}{l}\text { Both Packet } \\
\text { switching } \\
\text { and message } \\
\text { switching }\end{array}$ & $\begin{array}{l}\text { Both Packet } \\
\text { switching and } \\
\text { message } \\
\text { switching }\end{array}$ \\
\hline Coverage & $2-3 \mathrm{~km}$ & $8 \mathrm{~km}$ & Up to $50 \mathrm{~km}$ \\
\hline
\end{tabular}

\section{CONCLUSION}

RoF and WiMAX have been studied. In this paper, provide review of the progress RoF and WiMAX combination. The RoF and WiMAX are enables different functionality. But the multiplexing concept is coinciding. Here to carry out the WDM of RoF and OFDM of WiMAX keying concept is possible. So it will support to the future broadband access technology and upcoming mobile generation in the world and in the WDM-OFDM application to support many broadband and mobile generation technologies. And additionally, RoF techniques smoothly merged with broadband access with optical networks like in the WDM, OFDM and OFM. So at particularly OFDMA for mobile will provide carrying lot of possible solution. From the literature table author observed that research and development of future RoF-WiMAX architecture and it made to support many protocols in the optical and RF signals.

\section{REFERENCES}

[1] Mazin Al Noor, Green Radio Communication Networks Applying Radio-over-Fiber Technology for Wireless Access, Ph.D Thesis, 2011.

[2] Christina Lim, Ampalavanapillai Nirmalathas, Masuduzzaman Backul, Prasanna Gamage, Ka Lun Lee, Yizhuo Yang, Dalma Novak and Rod Waterhouse. "Fiber-Wirless Networks and Subsystem Technologies" Journal of Lightwave Technology, Vol. 28, No. 4, Feb. 15,2010 .

[3] Navid Ghazisaidi and Martin Maier, "Fiber-Wireless (FiWi) Networks: Comparative Techno Economic Analysis of EPON and WiMAX" IEEE Communication Society, 2009. 
[4] Anthony Ng'oma, Radio-over -Fiber Technology for Broadband Wirless Communication Systems, Ph.D Thesis, 2005.

[5] Springer: "Mobile Broadband Including WiMAX and LTE" by Mustafa Ergen, E-Book, e-ISBN: 978-0-38768192-4.

[6] Wiley: "WiMAX Evolution Emerging Technologies and Applications" by Marcos D. Katz and Frank H.P. Fitzek. ISBN: 978-0-470-69680-4.

[7] Springer: "WiMAX Networks Techno-Economic Vision and Challenges" by Prasad, R and Velez, F. J. E-Book. ISBN: 978-90-481-8751-5.

[8] N. Mohamed, S.M. Idrus, A.B. Mohammad, H. Harun, R. Mohammad and S. Yaakab, "Frequency UpConversion Technique for Radio over Fiber (RoF) Remote Antenna Unit Configuration" The Open Electrical \& Electronic Engineering Journal, 2012, 6, 7 13.

[9] Ajay Kumar Vyas, Dr. Navneet Agrawal, "Radio over Fiber: Future Technology of Communication" International Journal of Emerging Trends and Technology in Computer Science (IJETTCS). Volume 1, Issue 2, July-August 2012, ISSN 2278-6856.

[10] Beena R Ballel and Dr. Shikha Nema, "Digital Radio over Fiber Link to Overcome Impairments in Fiber Wireless Networks" IOSR Journal of Engineering, May 2012, Vol. 2(5), pp: 699-970.

[11] Haruka Mikamori and Koyu Chinen, "WiMAX RoF Design for Cost Effective Access Points" World Academy of Science, Engineering and Technology 2011.

[12] Jiang Liu, Wasinee Noonpakdee, Shigeru Schimamoto, "Design and Performance Evaluation of OFDM-Based
Wirless Services Employing radio over Optical Wireless Link" International Journal of Wirless \& Mobile Networks (IJWMN), Vol. 3, No.5, October, 2011.

[13] T. Tsagklas and F.N. Pavlidou, "A Survey on Radio and Fiber FiWi Network Architectures" Journal of Selected Areas in Telecommunications (JSAT), March Edition, 2011.

[14] Mazin Al-Noor, Jonathan Loo, Richard Comley, "Extended Mobile WiMAX Signal Transmission over RoF via Triple Symmetrical Dispersion System SMF, DCF and CFBG" International Journal on Advanced in Telecommunications, Vol. 4, No. 1 \& 2, Dec-2011.

[15] Jalal J. Hamad Ameen, Widad Ismail and Sevia M. Idrus. "Radio Access Network Power Management Considering Radio over Fiber Technique for 4G Mobile System" WSEAS Transactions on Communications. Issue 3, Volume 10, March 2011. ISSN: 1109-2742.

[16] Navid Ghazisaidi and Martin Maier, "Fiber-Wireless (FiWi) Access Networks: A Survey" IEEE Communication Magazine, Feb. 2009.

[17] F. Simba, B.M. Mwinyiwiwa, E.M. Mjema, L. Trojer, N.H. Mvungi, "Broadband Access Technologies for Rural Connectivity in Developing Countries" International Journal of Research and Review in Computer Science (IJRRCS), Vol. 2, No. 2, April 2011.

[18] Beena R Ballel and Dr. Shikha Nema, "Performance Comparison of Analog and Digital Radio over Fiber Link" International Journal of Computer Science and Engineering Technology (IJCSET), Vol. 3, No. 6 June 2012. 